\title{
Recenzja
}

\section{Artur Żurawik, Ustrój sądownictwa w Polsce, Wydawnictwo C. H. Beck, Warszawa 2013, ss. 301}

Artur Żurawik podjął się trudnego zadania napisania monografii dotyczącej funkcjonowania sądownictwa w Polsce. Odrębność i niezależność władzy sądowniczej, umocowana w art. 173 Konstytucji RP, od pozostałych dwóch, tj. egzekutywy i legislatywy, nie eliminuje mimo wszystko powiązań, jakie zachodzą między nimi. Nadmieńmy tylko, że to organ władzy wykonawczej, prezydent RP, powołuje sędziów, zaś minister sprawiedliwości sprawuje nadzór administracyjny nad sądami powszechnymi i wojskowymi. Natomiast akty prawne, które uchwala parlament, są podstawą prawną działalności tychże sądów. Poruszenie zagadnienia o organizacji ustrojowej trzeciej władzy istotnie wypełnia lukę $w$ dotychczasowym stanie literatury naukowej w Polsce. Zauważalne bowiem jest to, iż do momentu publikacji recenzowanej książki nie istniała żadna pozycja, która omawiałaby kompleksowo powyższe zagadnienie. Fakt ten podkreśla Autor już we wstępie. Do 2013 r., w którym wydano recenzowaną monografię, na temat judykatywy można było czerpać informacje z komentarzy do ustaw i różnorodnych artykułów. Warte zaznaczenia jest to, że publikacja dotyczy ustroju sądów nie tylko powszechnych, ale także administracyjnych, wojskowych oraz Sądu Najwyższego. Jest zatem syntetyczna, co wpływa na jej wysoki walor.

Monografia została podzielona na cztery rozdziały. W pierwszym z nich, zatytułowanym „Zasady ustrojowe sądownictwa”, Autor charakteryzuje 
dziesięć zasad tyczących się funkcjonowania judykatywy w Polsce. Podkreślając, iż ustrój sądownictwa został oparty na wielu różnych zasadach prawnych, słusznie zauważa, że brakuje jednomyślności co do celu i konkretnego katalogu tychże zasad. Dla A. Żurawika istotne jest, że wspomniane zasady spełniają dużą rolę, harmonizując porządek prawny i zapewniając spójność norm prawnych. Wśród omawianych kwestii znajdują się m.in.: zasada demokratycznego państwa prawnego, podziału władzy, sądowego wymiaru sprawiedliwości, instancyjności oraz niezawisłości sędziowskiej. Na uwagę zasługuje scharakteryzowanie prawa do sądu uregulowanego w art. 45 ust. 1 Konstytucji RP. Autor, omawiając to zagadnienie, sięgnął bowiem nie tylko do krajowych regulacji, ale również unijnych. Powołując się na wyroki Trybunału Sprawiedliwości UE, powtórzył, iż sądy krajowe mają obowiązek zapewnić ochronę sądową uprawnień podmiotów prawa wynikających z prawa wspólnotowego. Zaś podążając za krajowym orzecznictwem Trybunału Konstytucyjnego, przypomniał, że jednym z fundamentalnych założeń demokratycznego państwa prawnego jest zasada dostępu obywateli do sądu. Uszczegółowiając tę kwestię, odnotujmy, że prawo do sądu obejmuje tak prawo do uruchomienia postępowania sądowego i prawo do odpowiednio ukształtowanej procedury sądowej, zgodnie z zasadami sprawiedliwości, jawności i dwuinstancyjności, jak i prawo do uzyskania wiążącego rozstrzygnięcia.

W rozdziale drugim, „Sądy w Polsce”, została omówiona szeroko pojęta organizacja sądów. Przedstawiono zasady tworzenia sądów oraz kompetencje i status prawny organów sądowych. Autor zasadnie stwierdza, że uregulowania dotyczące poszczególnych sądów nie są spójne. Opinia, iż przepisy ustrojowe sądownictwa w Polsce winny być zmienione przez ujednolicenie w celu zapewnienia korzystniejszego funkcjonowania, wydaje się słuszna. Dodatkowo podjęto się scharakteryzowania samorządu sędziowskiego i nadzoru na działalnością sądów. Artur Żurawik, przedstawiając stanowisko na temat samorządu sędziowskiego, zarzucił ustawodawcy brak konsekwencji w tworzeniu statusu organów różnych rodzajów sądów. Przykładem jest to, że w sądach administracyjnych zgromadzenia ogólne są organami samorządu sędziowskiego i równocześnie organami sądów. Natomiast w sądach powszechnych są jedynie organami samorządu. Podobna rozbieżność występuje w przypadku kolegiów sądów, które w sądownictwie powszech- 
nym są jedynie organami sądów, a w Sądzie Najwyższym również organami samorządu sędziowskiego. Kwestia dotycząca nadzoru administracyjnego sprawowana przez ministra sprawiedliwości jest dość kontrowersyjna. Artur Żurawik przyjmuje, że punktem zapalnym jest sprawowanie nadzoru administracyjnego w sądownictwie powszechnym i wojskowym przez organ egzekutywy. Jego zdaniem częsta zmiana władzy powoduje szereg zmian ustawodawczych, a odnoszących się nierzadko do ustroju sądownictwa. Jako najdobitniejszy przykład wskazuje ustawę z 27 lipca 2001 r. - Prawo o ustroju sądów powszechnych, która była nowelizowana już ponad pięćdziesiąt razy. Co więcej, zwraca uwagę na szerokie kompetencje ministra sprawiedliwości pozwalające na znoszenie sądów w drodze rozporządzenia czy przenoszenie sędziów bez ich zgody w inne miejsce służbowe. Autor wysuwa propozycję, by określić w drodze ustawy okręgi sądowe, w ramach których co najmniej jeden sąd danego szczebla istniałby obligatoryjnie, aby prawo do sądu wynikające z Konstytucji RP nie zostało ograniczone. Artur Żurawik uważa nadto, że kompetencja w przedmiocie przenoszenia sędziów bez ich zgody powinna zostać przekazana Krajowej Radzie Sądownictwa. Stwierdza bowiem, że decyzyjność w tej materii należąca do organu władzy wykonawczej narusza zasadę podziału władz, a zatem powoduje, że art. $75 \$ 2$ pkt. 2 Prawo o ustroju sądów powszechnych jest niezgodny z art. 180 ust. 2 Konstytucji RP. Pomimo szeregu negatywnych uwag na temat uprawnień ministra sprawiedliwości Autor wypowiedział się pozytywnie na temat kompetencji organu egzekutywy w zakresie zadań z ochrony prawnej, które nie są wymiarem sprawiedliwości. Wyraził akceptację, by nadzór obejmował działalność finansową oraz działalność związaną z zarządzaniem majątkiem i innymi podobnymi zadaniami. Do najważniejszego pomysłu reorganizacji nadzoru nad sądownictwem należy aprobata wyrażona przez Autora, by nadzór administracyjny nad sądami powszechnymi i wojskowymi został powierzony pierwszemu prezesowi Sądu Najwyższego. Propozycja ta nie bierze się znikąd. Jest ona wierną kopią rozwiązania zastosowanego w sądownictwie administracyjnym, gdzie prezes NSA sprawuje tenże nadzór. Wskażmy ponadto, że w omawianym rozdziale nie zabrakło opisu czynności sądów. Autor w sposób bardzo zrozumiały scharakteryzował m.in. wyroki, pomoc sądową i kary porządkowe. 
Rozdział trzeci pod tytułem „Sędziowie, referendarze, asystenci, pracownicy sądów i inne podmioty" jest najobszerniejszą częścią książki. To w nim sporo miejsca poświęcono kwestii powoływania sędziów, ich statusu, praw i obowiązków oraz odpowiedzialności dyscyplinarnej sędziów. Artur Żurawik przywołuje stosowne przepisy prawa, omawia je i opatruje koniecznym komentarzem. Zwraca jednak baczną uwagę na cenne w tej materii orzeczenia Trybunału Konstytucyjnego. W związku z istniejącym problemem dotyczącym braku środka odwoławczego od prezydenckiej odmowy powołania danej osoby na stanowisko sędziowskie za uzasadnione uważa zmianę modelu powoływania na stanowiska sędziowskie, a zarazem wprowadzenie obowiązkowego powoływania przez prezydenta RP kandydata wskazanego przez KRS. Uzupełnia swoją propozycję przez przypomnienie, że od uchwał Krajowej Rady Sądownictwa przysługuje odwołanie.

W ostatnim rozdziale pt. „Inne zagadnienia” zaprezentowano przede wszystkim działalność dwóch instytucji, tj. Krajowej Rady Sądownictwa oraz Krajowej Szkoły Sądownictwa i Prokuratury. Autor w swych rozważaniach wypowiada się na temat trudnej do jednoznacznego zakwalifikowania pozycji ustrojowej Krajowej Rady Sądownictwa. Jako przykład podaje określanie tej instytucji mianem quasi-korporacji sędziowskiej albo organu administracji państwowej, co stanowi problem w klasyfikacji. Prezentując natomiast ustrój i działalność Krajowej Szkoły Sądownictwa i Prokuratury, A. Żurawik wskazuje na duże znaczenie tej szkoły właśnie dla sądownictwa i prokuratury. Zaś za szczególnie istotną uważa działalność w zakresie prowadzenia aplikacji prawniczych.

Niewątpliwą zaletą monografii jest to, że zdecydowano się na omówienie, w sposób problemowy, poszczególnych sądów. Artur Żurawik charakteryzuje dane zagadnienie i odnosi się do wszystkich rodzajów sądów, co jest niezwykle pomocne w zrozumieniu organizacji sądownictwa i nie bez znaczenia pozostaje przy wyciąganiu należytych wniosków. Natomiast dużą wartość pracy stanowi uwzględnienie licznego orzecznictwa tak krajowego, jak i międzynarodowego. Książka, mimo niezaprzeczalnych zalet, ma również i niedostatki. Do nich zaliczę zupełne pominięcie charakterystyki kuratorów sądowych, biegłych sądowych oraz urzędników i innych pracowników sądowych. Wady te jednak nie wpływają na ogólną wartość pozycji. Oparcie publikacji na szerokiej bazie źródłowej i stworzenie syntetycznej 
monografii omawiającej ustrój judykatywy w Polsce wraz z ważnymi postulatami i wnioskami Autora $\mathrm{z}$ całą pewnością stanowi cenny wkład w naukę. Zatem recenzowana publikacja w całości zasługuje na uważną lekturę tak teoretyków, jak i praktyków.

Elżbieta Gudowska Uniwersytet Jagielloński w Krakowie 